\title{
Ameliorative potential of Butea monosperma on chronic constriction injury of sciatic nerve induced neuropathic pain in rats
}

\author{
VENKATA R.K. THIAGARAJAN ${ }^{1,2}$, PALANICHAMY SHANMUGAM ${ }^{3}$, UMA M. KRISHNAN ${ }^{4}$, \\ ARUNACHALAM MUTHURAMAN ${ }^{5}$ and NIRMAL SINGH ${ }^{5}$ \\ ${ }^{1}$ School of Chemical and Biotechnology, Sastra University, Thanjavur-613401, Tamilnadu, India \\ ${ }^{2}$ Department of Pharmacognosy, College of Pharmacy, Madurai Medical College, Madurai-625011, Tamilnadu, India \\ ${ }^{3}$ Department of Pharmaceutical Sciences and Research, Sankaralingam Bhuvaneshwari College of Pharmacy, \\ Thiruthangal, Sivakasi-626123, Tamilnadu, India \\ ${ }^{4}$ Center for Nanotechnology and Advanced Biomaterials, School of Chemical \& Biotechnology, \\ SASTRA University, Thanjavur-613401, India \\ ${ }^{5}$ Department of Pharmaceutical Sciences and Drug Research, Punjabi University, Patiala-147002, India
}

Manuscript received on July 12, 2011; accepted for publication on April 13, 2012

\begin{abstract}
The present study was designed to investigate the ameliorative role of ethanolic extract from leaves of Butea monosperma in chronic constriction injury (CCI) of sciatic nerve induced neuropathic pain in rats. Hot plate, acetone drop, paw pressure, Von Frey hair and tail immersion tests were performed to assess the degree of thermal hyperalgesia, cold chemical allodynia, mechanical hyperalgesia \& allodynia in the left hind paw and tail thermal hyperalgesia. Further on, thiobarbituric acid reactive substances (TBARS), reduced glutathione (GSH) and total calcium levels were estimated to assess the biochemical changes in the sciatic nerve tissue. Histopathological changes were also observed in the sciatic nerve tissue. Ethanolic extract of Butea monosperma leaves and pregabalin (serving as positive control) were administered for 14 consecutive days starting from the day of surgery. CCI resulted in significant changes in behavioural and biochemical parameters. Pretreatment of Butea monosperma attenuated CCI induced development of behavioural, biochemical and histopathological alterations in a dose dependent manner, which is comparable to that of pregabalin pretreated group. These findings may be attributed to its potential anti-oxidative, neuroprotective and calcium channel modulatory actions of Butea monosperma.
\end{abstract}

Key words: anti-oxidant, Butea monosperma, calcium, chronic constriction injury, reduced glutathione, thiobarbituric acid reactive substance.

\section{INTRODUCTION}

Neuropathic pain is a chronic maladaptive neurodegenerative disorder, it is clinically well characterized by various sensory abnormalities (i.e., spontaneous pain, hyperalgesia, hypothesia, dysthesias and allodynia) (Woolf and Mannion 1999). Peripheral

Correspondence to: Venkata Rathina Kumar Thiagarajan E-mail: vrkmmcmadurai@gmail.com neuropathic pain is commonly seen with other disease (i.e., cancer, AIDS, diabetes, leprosy, multiple sclerosis, and stroke patients), traumatic injury [i.e., lumbar disc syndrome, traumatic spinal cord \& brain injury, occupational nerve entrapment injury (i.e., computer typing work)] and postoperative surgery (Koltzenburg and Scadding 2001, Alston and Pechon 2005, Bennett and Xie 1988). CCI 
induced neuropathy in experimental animals refers to Complex Regional Pain Syndrome (CRPS) in humans, which is common following fracture, total knee arthroplasty and stroke (Pramod 2006, Daviet et al. 2002, Kramer et al. 2009, Nagler 2010).

Conventional medicines such as anti-convulsant (gabapentin, pregabalin and carbamazepine), antidepressants (amitriptyline and duloxetine), topical treatments (lidocaine patch, capsaicin), and opioids are unable to alleviate the neuropathic pain (Dworkin et al. 2010, Lee and Nandi 2010). These studies have also reported to exhibit wide spectrum of adverse effects which limit their full clinical exploitation in the management of painful neuropathy (Carol and Jane 2006). Moreover, none of the medication assessed in randomized controlled studies has been found effective in CRPS (Kalita et al. 2006). There is an urgent need of an alternative medicine for the effective management of neuropathy particularly in CRPS.

Various studies have experimentally reported that, herbal medicine can produce beneficial effect on the management of painful neuropathy i.e., Aconiti tuber, Lindera angustifolia, Teucrium polium, Phyllanthus emblica, Vochysia divergens, Cannabis sativa, Nigella sativa, Ocimum sanctum and Ginkgo biloba (Kim et al. 2009, Muthuraman et al. 2008a). Clinical reports have also been documented to provide beneficial effect of herbal drugs in neuropathic pain management (Babbar et al. 2009, Ellis et al. 2009). Butea monosperma (family: Fabaceae), also known as flame of the forest, which is distributed in deciduous forest and in open areas (Gurav et al. 2008) has The leaves, flowers, stem bark and seeds that have been used in traditional medicine as diuretic, anti-diabetic, anthelmintic, anti-microbial, arthritis, wound healing as well as treating burning sensation of the body (Krithikar and Basu 1989, Varier 1995). Experimental reports have also been indicated to possess antiinflammatory, anti-convulsant, and anti-tumour activities (Shahavi and Desai 2008, Kasture et al. 2000, Sehrawat and Sultana 2006). Leaves have also been reported to possess hypoglycemic (Sharma and Garg 2009), ocular anti-inflammatory (Mengi and Deshpande 1995), anti-stress, and anti-anxiety (Soman et al. 2004) actions. Butea monosperma leaves are composed of various bioactive constituents such as euphane triterpenoid, flavonoids, tannins and sterols (Shukla et al. 2002). Fresh decoction of Butea monosperma is commonly used to relieve muscular pain, joint pain and severe headache in some areas of Tamilnadu at Thiruvannamalai, Theni, and Madurai region of India. An ayurvedic formulation namely Mahanarayana taila is used to treat neuralgia being prepared from this plant (Anonymous 2006). However, experimentally its analgesic potential in neuropathic pain remains to be explored.

Hence the present investigation has been undertaken to explore potential of Butea monosperma in CCI induced neuropathic pain in rats. Pregabalin binds to the $\alpha 2-\delta$ site an auxiliary subunit of voltagegated calcium channels in the CNS, inhibiting excitatory neurotransmitter release. This drug has proven partial effects onset seizures, neuropathic pain associated with diabetic peripheral neuropathy, postherpatic neuralgia, and fibromyalgia (Kumar et al. 2010). Therefore, pregabalin (voltage dependent calcium channel antagonist) serves as a positive control in this investigation.

\section{MATERIALS AND METHODS}

Plant MATERIAL

Fresh leafy parts of Butea monosperma were collected from Madurai and authenticated by Dr. D. Stephen, Asst Prof., Department of Botany, American College, Madurai. Plant sample have been kept in the Department of Pharmacognosy, (Voucher specimen n\#: BM. 001/2007-2008), College of Pharmacy, Madurai Medical College, Madurai.

\section{EXTRACTION}

The fresh leafy part of Butea monosperma was shade dried at room temperature and reduced to coarse powder (sieve n\#. 10/40). The dried powdered 
leaves of Butea monosperma (500 g) were defatted with petroleum ether and then extracted with ethanol (95\%) in a Soxhlet apparatus as described in the method of Suzgec-Selcuk and Birteksoz (2011). Ethanolic extract was concentrated under reduced pressure until dryness (yield $14.56 \%$ ).

CHEMiCALS

5, 5'-dithio, bis (2-nitrobenzoic acid) (DTNB), bovine serum albumin (BSA), and reduced glutathione were purchased from Sisco Research Laboratories, Mumbai. Thiobarbituric acid was purchased from Loba Chemie, Mumbai. All other reagents were obtained from SD Fine chemicals, Mumbai, India.

\section{ANIMALS}

Wistar rats of both sexes weighing 180-250 g, maintained on standard laboratory diet (Kisan Feeds Ltd., Mumbai, India) and having free access to tap water were employed in the present study. They were housed in the departmental animal house and were exposed to 12 hour cycle of light and dark. The experimental protocol was approved by the Institutional Animal Ethics Committee (IAEC) and animal care was carried out in accordance to the guidelines of the Committee For the Purpose of Control and Supervision of Experiments on Animals (CPCSEA), Ministry of Environment and Forest, Government of India (Ref. N\#. 2360/ E2/4/2010/IAEC).

\section{INDUCTION OF PERIPHERAL NEUROPATHY}

Painful peripheral neuropathy was induced in experimental animals by chronic constriction injury as described in the method of Bennett and Xie (1988), with slight modifications of Sommer and Schafers (1998). In brief, rats were anesthetized with thiopental sodium (35 mg/kg, i.p.). The skin of the lateral surface of the left thigh was incised and a cut was made directly through the biceps femoris muscle to expose the sciatic nerve. Four loose ligatures (silk 4-0), were placed around the nerve proximal part of the trifurcation with a distance of $1 \mathrm{~mm}$ between each ligature. The ligatures were loosely tied until a short flick of the ipsilateral hind limb was observed. After performing nerve ligation, muscular and skin layer was immediately sutured with thread, and topical antibiotic was applied at once. Nociceptive threshold was assessed before and after performing surgery on different days i.e. $0,1,3,6,9,12,15,18$, and $21^{\text {st }}$ day.

\section{EXPERIMENTAL DESIGN}

Ten groups, each comprising six Wistar rats were employed in the present study.

Group I (Normal control group): Rats were not subjected to any surgical procedure and were kept for 21 days.

Group II (Sham control group): Rats were subjected to surgical procedure to expose the left sciatic nerve without any nerve ligation process.

Group III (CCI control group): Rats were subjected to surgical procedure to expose the left sciatic nerve with nerve ligation process.

Group IV (CCI + Vehicle treated group): After subjecting the rats to chronic constriction injury of sciatic nerve, $1 \%$ carboxy methyl cellulose was administered orally for 14 consecutive days from the day of surgery.

Group $V$ (BM per se): Rats were subjected to administration of ethanolic extract of Butea monosperma (400 mg/kg, p.o.) for 14 consecutive days.

Group VI (Pregabalin per se): Rats were subjected to administration of pregabalin $(10 \mathrm{mg} / \mathrm{kg}$, p.o. $)$ for 14 consecutive days from the day of surgery.

Group VII to IX (CCI + BM treated group): After subjecting the rats to CCI, ethanolic extract of Butea monosperma was administered from the day of surgery respectively: 200, 300, and $400 \mathrm{mg} / \mathrm{kg}$, p.o. for 14 consecutive days. 
Group X (CCI + Pregabalin treated group): After subjecting the rats to CCI, pregabalin $(10 \mathrm{mg} / \mathrm{kg}$, p.o. for 14 consecutive days) was administered from the day of surgery.

All the groups of animals were employed to assess behavioural tests to determine the degree of nociceptive threshold on certain day intervals, i.e., $0,1,3,6,9,12,15,18$ and $21^{\text {st }}$ day. All the animals were sacrificed at end of the $21^{\text {st }}$ day and biochemical analysis was carried out in sciatic nerve tissue homogenate for estimation of total protein content, thiobarbituric reactive substance (TBARS), reduced glutathione and total calcium levels.

\section{BEHAVIOURAL STUDIES}

\section{Heat hyperalgesic test}

Heat thermal sensitivity of the hind paw was assessed by using Eddy's hot plate as described method of Eddy et al. (1950) with slight modification for assessing the degree of noxious thermal sensation. The rats were placed on the top of a preheated $\left(52.5^{\circ} \pm 0.5^{\circ} \mathrm{C}\right)$ hot plate surface, allowing access to the left hind paw withdrawal response to degree of the nociceptive threshold. The cut-off time of 20 s was maintained.

\section{Cold chemical allodynic test}

Cold chemical thermal sensitivity of the hind paw was assessed using acetone drop method as described by Choi et al. (1994) with slight modification for assessing the reactivity to nonnoxious cold chemical stimuli. The rats were placed on the top of a wire mesh grid, allowing access to the hind paws. Acetone $(100 \mu \mathrm{L})$ was sprayed on the plantar surface of rat's left hind paw. Cold chemical sensitive reaction with respect to either paw licking, shaking or rubbing the left hind paw was observed and recorded as paw withdrawal threshold. The cutoff time of 20s was maintained.

\section{Mechanical hyperalgesic test}

Mechanical sensation of the hind paw as an index of mechano-hyperalgesic test was assessed by pressure stimulation method as described by Randall and Selitto (1957). Briefly, mechanical nociceptive threshold, expressed in grams, as measured by applying increasing pressure to the left hind paw. Withdrawal of left hind paw was used to assess the mechanical nociceptive threshold. The cut-off pressure $450 \mathrm{~g}$ was maintained.

\section{Mechanical allodynia test}

Mechanical sensation of the hind paw as an index of mechano-allodynia was assessed as described method of Chaplan et al. (1994). Briefly, calibrated nylon filaments, in terms of different bending forces, were applied to the mid plantar surface of left hind paw. The filaments were applied ten times, starting with the softest and continuing in ascending order of stiffness. A brisk withdrawal of the left hind limb was considered as a positive response. The criterion for the threshold value, in grams, was equal to the filament evoking a withdrawal of the paw 5 times out of 10 trials i.e., $50 \%$ response. The cut-off pressure $30 \mathrm{~g}$ was maintained.

\section{Tail heat hyperalgesic test}

Spinal thermal sensitivity was assessed by the tail immersion test as described method of Necker and Hellon (1978). Briefly, the terminal part of the rat's tail $(1 \mathrm{~cm})$ was immersed in heat-noxious temperature $\left(52^{\circ} \pm 0.5^{\circ} \mathrm{C}\right)$, until the tail was withdrawn. The duration of the tail withdrawal reflex was used to assess the thermal heat hyperalgesia. The cut-off time of $10 \mathrm{~s}$ was maintained.

BIOCHEMICAL ESTIMATION OF MARKERS OF

OXIDATIVE STRESS

After 21 days of surgery, animals were sacrificed by cervical dislocation and sciatic nerve was 
immediately isolated from the body. The proximal part of sciatic nerve tissue homogenate $(10 \%, \mathrm{w} / \mathrm{v})$ was prepared with $0.1 \mathrm{M}$ Tris-HCl buffer ( $\mathrm{pH}$ 7.4) and supernatant of homogenate was employed to estimate total protein content, TBARS, reduced glutathione and total calcium content.

\section{Estimation of tissue protein}

Protein concentration was estimated according to the method of Lowry et al. (1951), using bovine serum albumin (BSA) as a standard. The absorbance was determined spectrophotometrically at $750 \mathrm{~nm}$.

\section{Estimation of lipid peroxidation}

Estimation of lipid peroxidation was done by measuring the levels of malondialdehyde [MDA: thiobarbituric acid reactive substances (TBARS)] as the described method of Okhawa et al. (1979). The concentration of TBARS in tissue homogenate was expressed in terms of nmol of malondialdehyde per mg of protein. 1,1,3,3-Tetramethoxypropane (1-10 nmol) was used as the standard.

\section{Estimation of reduced glutathione}

Reduced glutathione was measured as described method of Ellman (1959). Equal quantity of sciatic nerve homogenate was mixed with $10 \%$ trichloroacetic acid and centrifuged to separate proteins. To $10 \mu \mathrm{L}$ of this supernatant, $2 \mathrm{~mL}$ of phosphate buffer ( $\mathrm{pH} 8.4$ ), $500 \mu \mathrm{L}$ of 5, 5'-dithio, bis (2-nitrobenzoic acid) and $400 \mu \mathrm{L}$ double distilled water were added. Mixture was vortexed and the absorbance was taken at $412 \mathrm{~nm}$ within $15 \mathrm{~min}$. The concentration of reduced glutathione was expressed as $\mu \mathrm{g}$ per mg of protein in sciatic nerve tissue.

\section{Estimation of total calcium}

Total calcium levels were estimated in sciatic nerve tissue as described method of Severinghaus and Ferrebee (1950) with slight modification of Muthuraman et al.(2008b). Briefly, sciatic nerve tissue homogenate was mixed with $1 \mathrm{~mL}$ of trichloroacetic acid (4\%) in ice cold conditions and centrifuged at 2,000 r.p.m. for 10 minutes. The clear supernatant was used for the estimation of total calcium ion by atomic emission spectroscopy at $556 \mathrm{~nm}$.

Histopathological Assessment

Samples of sciatic nerve were stored in the fixative solution ( $10 \%$ formalin) and cut into $4 \mu \mathrm{m}$ thickness. Staining was done by using hematoxylin and eosin (H \& E) as described method of Sudoh et al. (2004). Nerve sections were analyzed qualitatively under light microscope $(450 \mathrm{X})$ for axonal degeneration.

\section{Statistical analysis}

All the results were expressed as standard error of mean (SEM). Data obtained from behavioural tests were statistically analyzed by using twoway repeated ANOVA, while data of biochemical parameters was analyzed using one way ANOVA. In both cases, Tukey's multiple range test were applied for post-hoc analysis. A value of $p<0.05$ was considered to be statistically significant.

\section{RESULTS}

EFFECT OF BUTEA MONOSPERMA ON

HeAt Hyperalgesic Test

Chronic constriction injury (CCI) of sciatic nerve resulted in significant development of noxious thermal hyperalgesia, indicated by decrease in left hind paw withdrawal threshold, after the $3^{\text {rd }}$ day of surgery as compared to sham control. Administration of ethanolic extract of Butea monosperma (BM 200, 300, and 400 $\mathrm{mg} / \mathrm{kg}$, p.o.) attenuated CCI induced decrease in the nociceptive threshold for thermal hyperalgesia in a dose dependent manner. Treatment of pregabalin also produced similar effects. However, statistically significant attenuation was recorded only with medium and high dose of Butea monosperma. Further, vehicle, BM per se and pregabalin did not show any significant effect on heat hyperalgesic test (Fig. 1). 


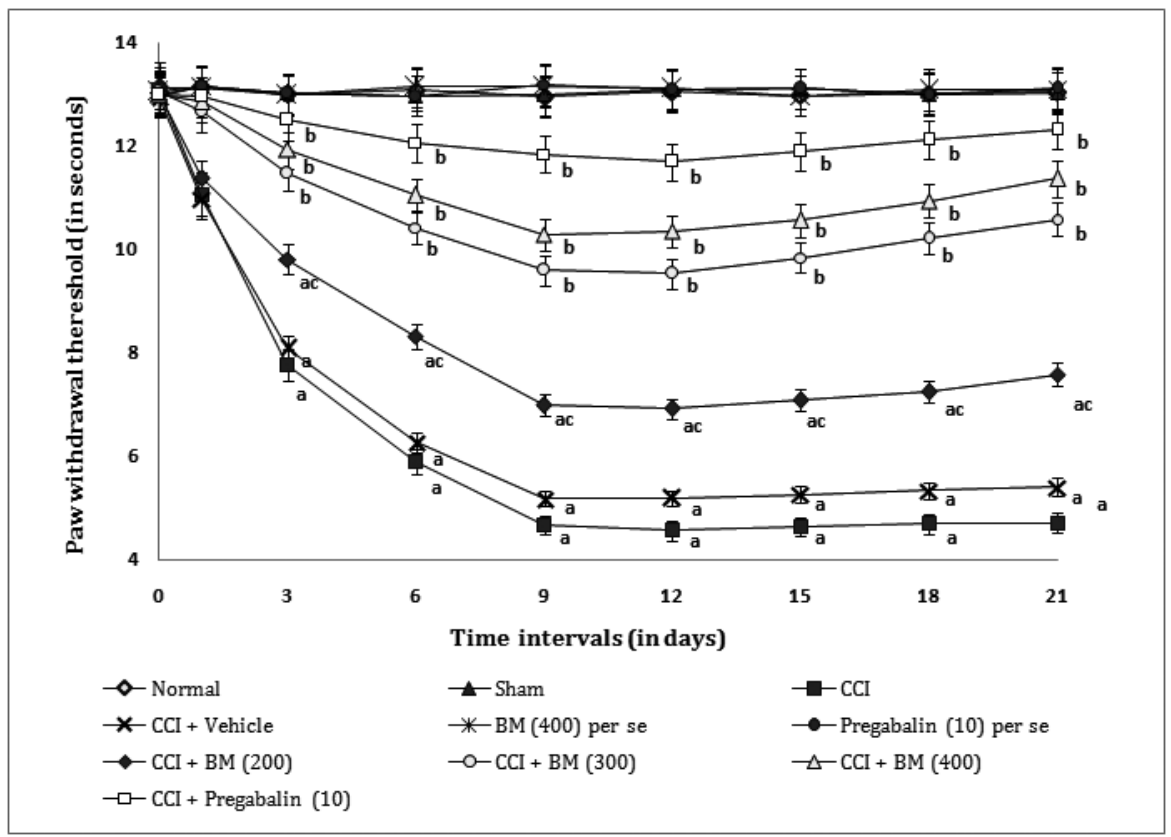

Fig. 1 - Effect of Butea monosperma on paw heat hyperalgesia.

Digits in parenthesis indicate dose in $\mathrm{mg} / \mathrm{kg}$.

Data were expressed as mean $\pm \mathrm{SEM}, \mathrm{n}=6$ rats per group.

${ }^{\mathrm{a}} p<0.05$ vs sham control group.

${ }^{\mathrm{b}} p<0.05$ vs CCI control group.

${ }^{\mathrm{c}} p<0.05$ vs pregabalin treated group.

\section{EFFECT OF BUTEA MONOSPERMA ON}

\section{Cold Chemical Allodynic Test}

Chronic constriction injury of sciatic nerve resulted in significant development of non-noxious cold chemical allodynia, indicated by decrease in left hind paw withdrawal threshold, after the $3^{\text {rd }}$ day of surgery as compared to sham control. Administration of ethanolic extract of Butea monosperma (BM 200, 300, and $400 \mathrm{mg} / \mathrm{kg}$, p.o.) attenuated CCI induced decrease in the nociceptive threshold for thermal allodynia in a dose dependent manner. Treatment of pregabalin also produced similar effects. However, statistically significant attenuation was recorded only with medium and high dose of Butea monosperma. Further, vehicle, Butea monosperma per se and pregabalin did not show any significant effect on cold chemical allodynic test (Fig. 2).
EFFECT OF BUTEA MONOSPERMA ON

\section{MECHANICAL HyPERALGESIC TEST}

Chronic constriction injury of sciatic nerve resulted in significant development of noxious static mechanical hyperalgesia, indicated by decrease in left hind paw withdrawal threshold, after the $3^{\text {rd }}$ day of surgery as compared to sham control. Administration of ethanolic extract of Butea monosperma (BM 200, 300, and $400 \mathrm{mg} / \mathrm{kg}$, p.o.) attenuated CCI induced decrease in the nociceptive threshold for mechanical hyperalgesia in a dose dependent manner. Treatment of pregabalin also produced similar effects. However, statistically significant attenuation was recorded only with medium and high dose of Butea monosperma. Further, vehicle, Butea monosperma per se and pregabalin did not show any significant effect on mechanical hyperalgesic test (Fig. 3). 


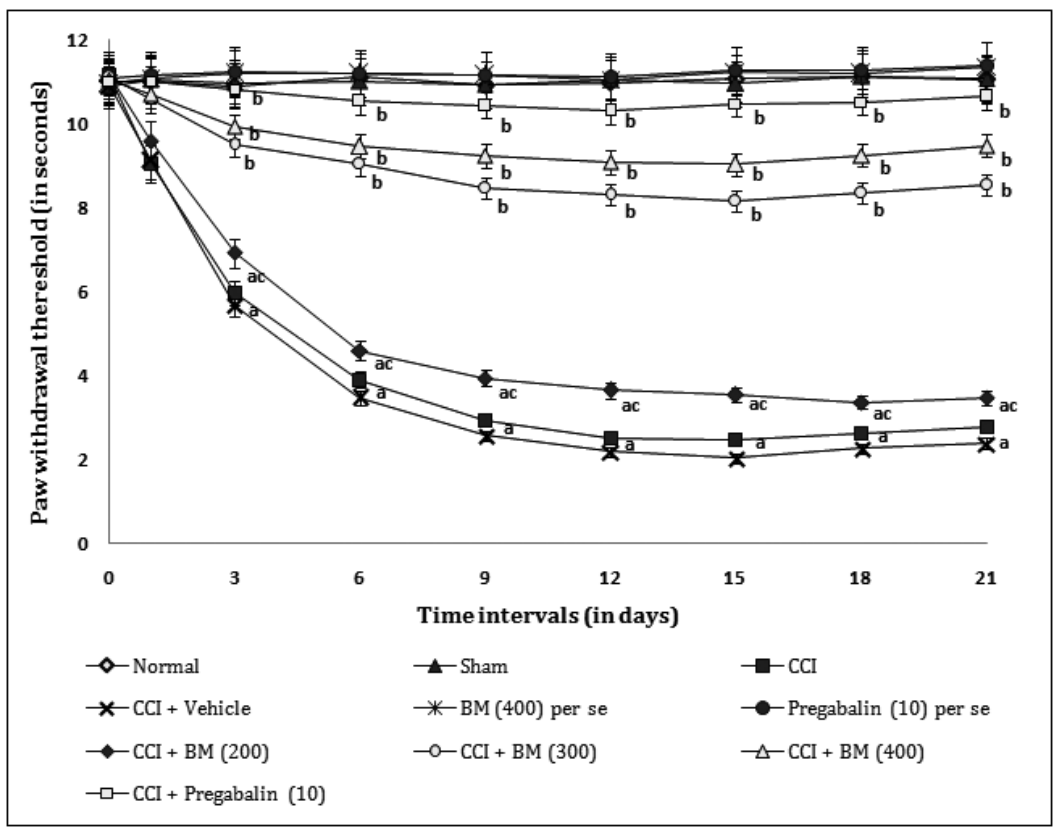

Fig. 2 - Effect of Butea monosperma on paw cold allodynia Digits in parenthesis indicate dose in $\mathrm{mg} / \mathrm{kg}$.

Data were expressed as mean $\pm \mathrm{SEM}, \mathrm{n}=6$ rats per group.

${ }^{\mathrm{a}} p<0.05$ vs sham control group.

${ }^{\mathrm{b}} p<0.05$ vs CCI control group.

${ }^{\mathrm{c}} p<0.05$ vs pregabalin treated group.

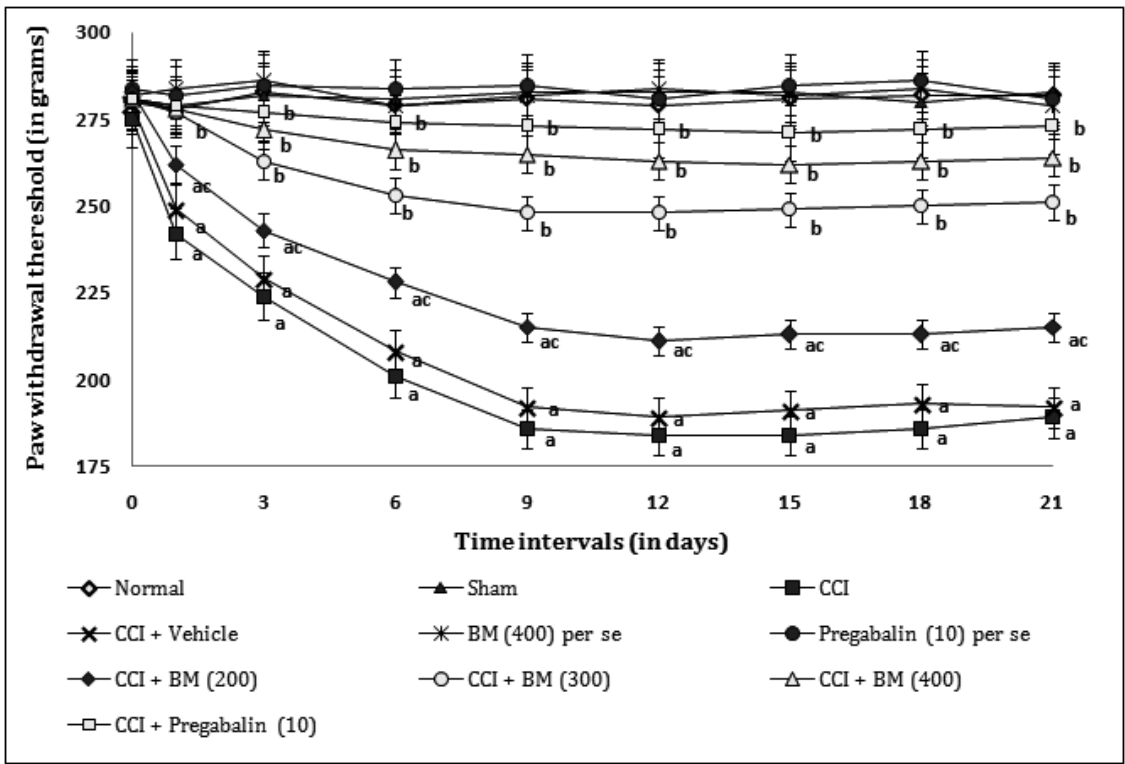

Fig. 3 - Effect of Butea monosperma on paw mechanical hyperalgesia

Digits in parenthesis indicate dose in $\mathrm{mg} / \mathrm{kg}$.

Data were expressed as mean $\pm \mathrm{SEM}, \mathrm{n}=6$ rats per group.

${ }^{\mathrm{a}} p<0.05$ vs sham control group.

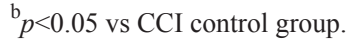

${ }_{p}^{\mathrm{c}}<0.05$ vs pregabalin treated group. 
EFFECT OF BUTEA MONOSPERMA ON

\section{Mechanical Allodynic Test}

Chronic constriction injury of sciatic nerve resulted in significant development of non-noxious tactile mechanical hyperalgesia, indicated by decrease in left hind paw withdrawal threshold, after the $3^{\text {rd }}$ day of surgery as compared to sham control. Administration of ethanolic extract of Butea monosperma (BM 200, 300 , and $400 \mathrm{mg} / \mathrm{kg}$, p.o.) attenuated CCI induced decrease in the nociceptive threshold for mechanical hyperalgesia in a dose dependent manner. Treatment of pregabalin also produced similar effects. However, statistically significant attenuation was recorded only with medium and high dose of Butea monosperma. Further, vehicle, Butea monosperma per se and pregabalin did not show any significant effect on mechanical hyperalgesic test (Fig. 4).

\section{EFFECT OF BUTEA MONOSPERMA ON}

\section{TAIL HEAT HYPERALGESIC TEST}

Chronic constriction injury of sciatic nerve resulted in significant development of noxious tactile mechanical hyperalgesia, indicated by decrease in tail withdrawal threshold, after the $3^{\text {rd }}$ day of surgery as compared to sham control. Administration of ethanolic extract of Butea monosperma (BM 200, 300 , and $400 \mathrm{mg} / \mathrm{kg}$, p.o.) attenuated CCI induced decrease in the nociceptive threshold for mechanical hyperalgesia in a dose dependent manner. Treatment of pregabalin also produced similar effects. However, statistically significant attenuation was recorded only with medium and high dose of Butea monosperma. Further, vehicle, Butea monosperma per se and pregabalin did not show any significant effect on tail heat hyperalgesic test (Fig. 5).

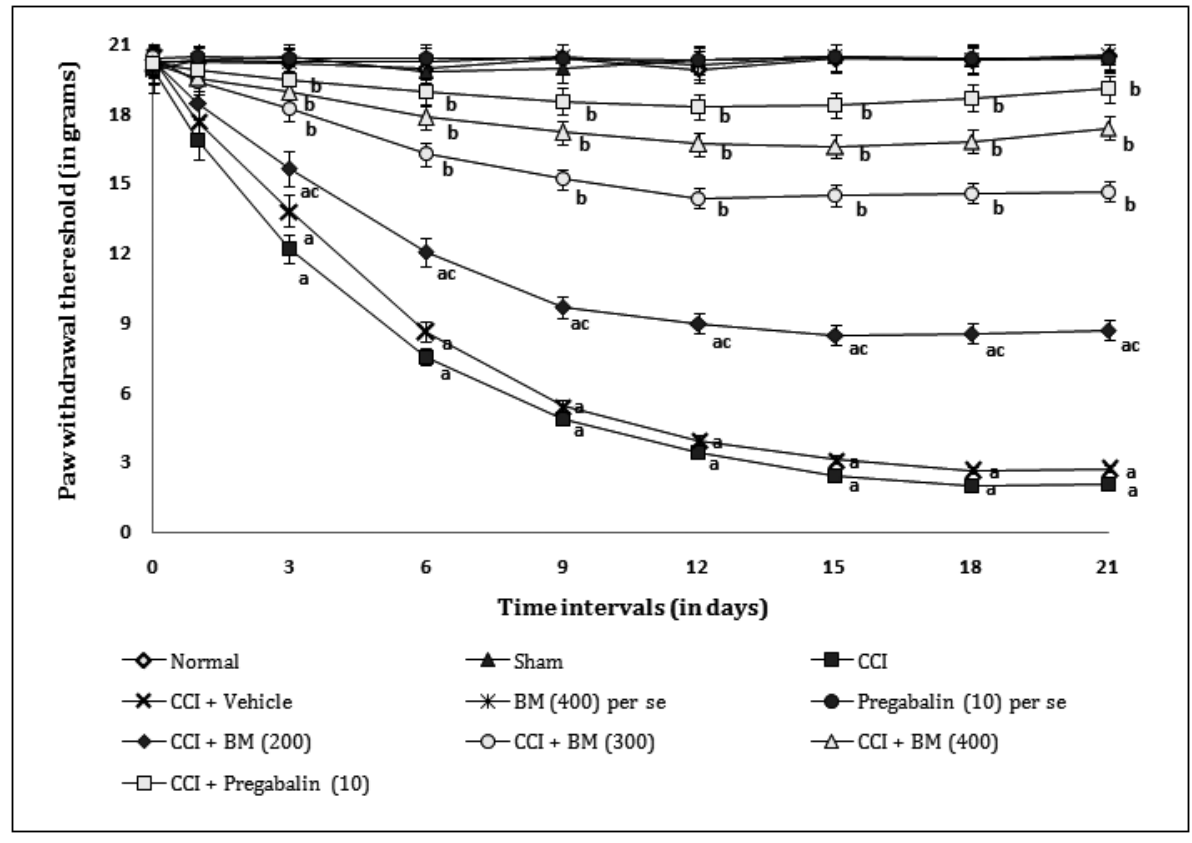

Fig. 4 - Effect of Butea monosperma on paw mechanical allodynia Digits in parenthesis indicate dose in $\mathrm{mg} / \mathrm{kg}$.

Data were expressed as mean $\pm \mathrm{SEM}, \mathrm{n}=6$ rats per group. ${ }^{\mathrm{a}} p<0.05$ vs sham control group.

${ }^{\mathrm{b}} p<0.05$ vs CCI control group.

${ }^{c} p<0.05$ vs pregabalin treated group. 


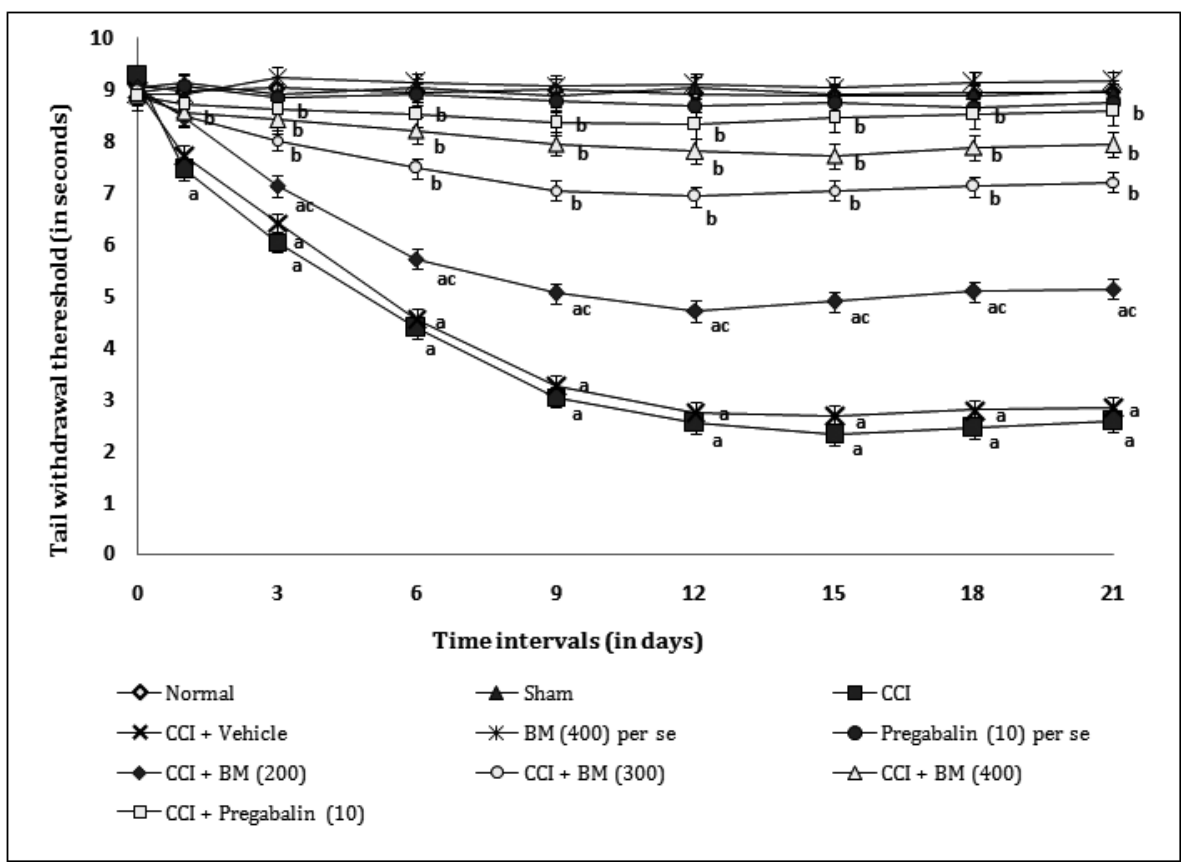

Fig. 5 - Effect of Butea monosperma on tail heat hyperealgesia Digits in parenthesis indicate dose in $\mathrm{mg} / \mathrm{kg}$.

Data were expressed as mean $\pm \mathrm{SEM}, \mathrm{n}=6$ rats per group.

${ }^{\mathrm{a}} p<0.05$ vs sham control group.

${ }^{\mathrm{b}} p<0.05$ vs CCI control group.

${ }^{\mathrm{c}} p<0.05$ vs pregabalin treated group.

\section{EFFECT OF BUTEA MONOSPERMA ON OXIDATIVE}

\section{STRESS MARKERS AND CALCIUM LEVELS}

Sciatic nerve ligation resulted in significant rise in TBARS, total calcium levels and decreased in the levels of reduced glutathione, after the $21^{\text {st }}$ day of surgery as compared to sham control. Administration of the ethanolic extract of Butea monosperma (BM 200, 300, and $400 \mathrm{mg} / \mathrm{kg}$, p.o.) attenuated $\mathrm{CCI}$ induced rise in sciatic nerve tissue thiobarbituric reactive substances (TBARS), total calcium and decrease in reduced glutathione levels in dose dependent manner. Treatment of pregabalin also produced similar effects. Further, vehicle, Butea monosperma per se and pregabalin did not show any significant effect on biochemical levels (Table I).

\section{EFFECT OF BUTEA MONOSPERMA ON}

HistopathologicAl CHANGES

Chronic constriction injury of sciatic nerve resulted in significant histopathological changes assessed in transverses sections of the sciatic nerve. In transverse section, nerve derangement, axonal swelling, increase in number of Schwann \& satellite cells were also noted. Administration of the ethanolic extract of Butea monosperma (200, 300, and $400 \mathrm{mg}$ / $\mathrm{kg}$, p.o.) significantly attenuated CCI induced axonal degeneration and histopathological alterations (Fig. 6).

\section{DISCUSSION}

In the present study, Butea monosperma attenuated chronic constriction injury of sciatic nerve induced 
TABLE I

Effect of Butea monosperma on tissue biomarker changes.

\begin{tabular}{lccc}
\hline Groups & $\begin{array}{c}\text { MDA } \\
(\mathrm{nmol} / \mathrm{mg} \text { of protein) }\end{array}$ & $\begin{array}{c}\text { GSH } \\
(\mu \mathrm{g} / \mathrm{mg} \text { of protein })\end{array}$ & $\begin{array}{c}\text { Total calcium } \\
(\mathrm{ppm} / \mathrm{mg} \text { of protein })\end{array}$ \\
\hline Normal & $3.09 \pm 0.33$ & $74.42 \pm 2.36$ & $2.83 \pm 0.22$ \\
Sham & $3.12 \pm 0.39$ & $74.26 \pm 2.58$ & $2.94 \pm 0.31$ \\
CCI & $4.39 \pm 0.27^{\mathrm{a}}$ & $48.25 \pm 4.21^{\mathrm{a}}$ & $20.32 \pm 0.47^{\mathrm{a}}$ \\
Vehicle in CCI & $4.42 \pm 0.29^{\mathrm{a}}$ & $47.96 \pm 3.63^{\mathrm{a}}$ & $19.49 \pm 0.32^{\mathrm{a}}$ \\
BM (400) per se & $3.13 \pm 0.24$ & $74.41 \pm 2.63$ & $2.69 \pm 0.33$ \\
Pregabalin (10) per se & $3.09 \pm 0.34$ & $74.38 \pm 2.58$ & $2.85 \pm 0.39$ \\
$B M(200)$ in CCI & $4.26 \pm 0.35^{\mathrm{ac}}$ & $52.93 \pm 1.46^{\mathrm{ac}}$ & $17.86 \pm 0.27^{\mathrm{ac}}$ \\
BM(300) in CCI & $3.59 \pm 0.18^{\mathrm{b}}$ & $64.27 \pm 3.28^{\mathrm{b}}$ & $11.21 \pm 0.29^{\mathrm{b}}$ \\
$B M(400)$ in CCI & $3.34 \pm 0.37^{\mathrm{b}}$ & $69.87 \pm 2.46^{\mathrm{b}}$ & $8.18 \pm 0.36^{\mathrm{b}}$ \\
Pregabalin (10) in CCI & $3.27 \pm 0.19^{\mathrm{b}}$ & $72.51 \pm 2.43^{\mathrm{b}}$ & $5.02 \pm 0.19^{\mathrm{b}}$ \\
\hline
\end{tabular}

Digits in parenthesis indicate dose in $\mathrm{mg} / \mathrm{kg}$.

Data were expressed as mean \pm SEM for 6 rats per group.

${ }^{\mathrm{a}} p<0.05$ vs sham control group.

${ }_{p} p<0.05$ vs CCI control group.

${ }^{\mathrm{c}} p<0.05$ vs pregabalin treated group.

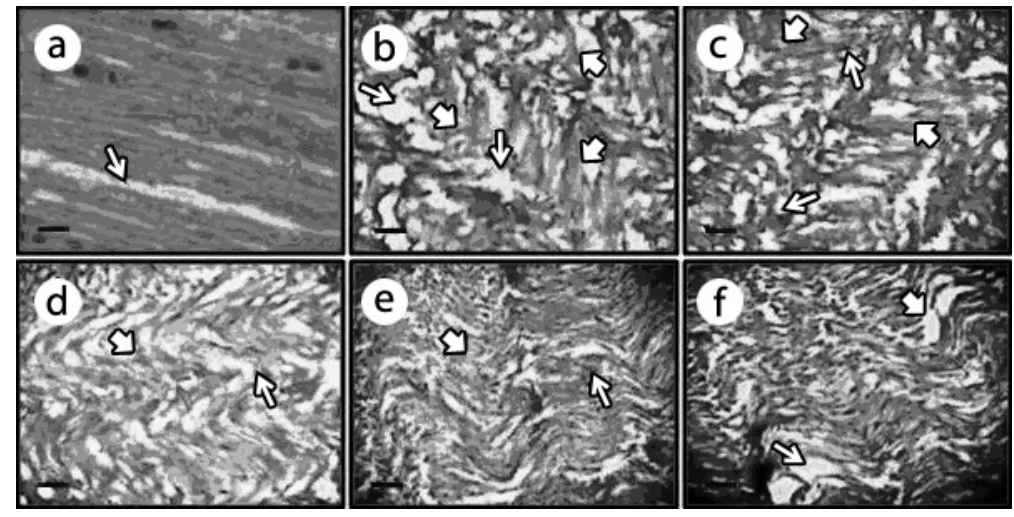

Fig. 6 - Effect of Butea monosperma on histopathological changes.

The transverse-section of sciatic nerve of sham, CCI, AC (200, 300 and $400 \mathrm{mg} / \mathrm{kg}$, p.o.) and pregabalin (10 mg/kg, p.o) pretreated groups shown in figures 6a-6f respectively. The thin arrow shows axonal swelling, bold arrow shows CCI induced changes in satellite and Schwann cells along with fiber derangement. CCI induced the axonal swelling, derangement of nerve fibers and expression of neuroglial cells (i.e., satellite and Schwann cells) shown in figures 6b. Pretreatment of Butea monosperma (200, 300 and $400 \mathrm{mg} / \mathrm{kg}$, p.o.) and pregabalin (10 mg/kg, p.o.) shown to produce the ameliorative effect in $\mathrm{CCI}$ induced histopathological changes (figures $6 \mathrm{c}-6 \mathrm{f}$,). Microscopic examination was carried out under light microcopy (magnification, $450 \mathrm{X}$ and scale bar, $35 \mu \mathrm{m}$ ).

behavioural [i.e., heat (paw \& tail) hyperalgesia, cold chemical allodynia, mechanical hyperalgesia \& allodynia], biochemical (TBARS, total calcium and reduced glutathione) and histopathological changes. Traditional medicines prepared from Emblica officinalis, Piper longum and Butea monosperma has been documented as a nervine tonic and used for a life span of 100 years with full vigour, cognitive functions and to preserve youth (Adams et al. 2007, Manyam 1999). Pippali rasayana, an ayurvedic herbal medicine, prepared from Piper longum and Butea monosperma has been proven for its traditional claim like immunomodulatory property (Agarwal et al. 1994, 1997). Methanolic extract of the flowers of this plant has been reported for in vitro anti-oxidant activity (Lavhale and Mishra 2007, Kostoff et al. 
2008). Further, leaves of this plant have also been used as a nerve tonic to alleviate disorders related to nerves and as analgesic in muscular pain, joint pain and severe headache. Ethanolic extract of leaves of Butea monosperma have shown to possess the anti-oxidant and anti-diabetic activity (Sharna and Garg 2009).

Free radical mediated oxidative damage has played major role in the pathogenesis of neurodegenerative disease (i.e., amyotrophic lateral sclerosis [ALS], Alzheimer's disease and Parkinson's disease) (Honda et al. 2004). Reactive oxygen and reactive nitrogen species have been documented to contribute the pathophysiological changes in diabetes and its complications (Gao et al. 2007), toxin, Freund's adjuvant induced inflammation, CCI and vincristine mediated neuropathy (Otto et al. 2003). The present study resulted in TBARS levels rise (an index of lipid peroxidation) \& total calcium and fall in the reduced glutathione (GSH, an endogenous anti-oxidant level). Thus supporting the contention that free radicals may contribute in pathogenesis of neuropathy. Moreover, the administration of ethanolic extract of Butea monosperma attenuated the CCI induced alterations of peripheral and central behavioural changes associated with oxidative stress marker changes in rats (Bandyopadhyay et al. 1999). Butea monosperma has been documented to decrease free radical generation via enhancement of anti-oxidant mechanisms (Sai Krishna et al. 2010). Free radicals have been reported to increase intracellular $\mathrm{Ca}^{2+}$ concentration along with activation of NMDA receptor, which has been considered having consanguineous relation with pain modulation (Stanciu et al. 2000). CCI induced increase in calcium levels in sciatic nerve has been documented in the present study as well as in earlier reports (Muthuraman et al. 2008b, Muthuraman and Singh 2011). Increase in calcium ions has been noted to induce electrical hyper-excitability, deplete ATP and activate calpains (Xie and Barrett 1991). Calcium induced activation of calpain is also associated with generation of reactive oxygen species form mitochondria (Carriedo et al. 2000).
Calcium-induced activation of calpains has been shown as responsible for the axonal degeneration by alteration of stability of axonal cytoskeleton protein (Glass et al. 2002, Muthuraman and Sood 2010).

Administration of Butea monosperma attenuated CCI induced rise in calcium ion, and oxidative stress markers which it may play a critical role in its anti-nociceptive effects in the development of painful neuropathy. The noted decrease in calcium levels with Butea monosperma may be attributed to its anti-oxidant effects as free radicals are well reported to increase calcium ions (Glass et al. 2002). However, the possibility of direct action of Butea monosperma on decrease in calcium levels may not be ruled out. Moreover, increase in calcium ions is also associated with increase in oxidative stress (Carriedo et al. 2000). So, the noted antioxidant effects of Butea monosperma may also be ascribed secondary to decrease in calcium ion levels. However, number of experimental reports indicating anti-oxidant effects of Butea monosperma in various studies (Lavhale and Mishra 2007, Sharrna and Garg 2009, Sai Krishna et al. 2010). Similar results were obtained in the pregabalin treated animals. Pregabalin is a potential voltage dependent calcium channel ( $\alpha 2-\delta$ subunit) antagonist (Kumar et al. 2010). It has also been reported to possess the potential role in the management of painful neuropathy in human (Kumar et al. 2010) and in experimental animal (Bender et al. 2010, Park et al. 2010). Ameliorative effect of Butea monosperma against chronic constriction injury of sciatic nerve induced neuropathic pain may be due to its potential of anti-oxidative, neuroprotective and inactivation of calcium channel opening. Nevertheless, further studies are needed to substantiate these findings.

\section{CONCLUSION}

Butea monosperma attenuated the chronic constriction injury of sciatic nerve induced behavioural, biochemical and histopathological changes. These effects may be due its anti-oxidant, neuroprotective 
and cellular calcium modulatory action. Perhaps, it may be explored as future medicine for the management of neuropathic pain syndrome.

\section{ACKNOWLEDGMENTS}

The authors are grateful to Prof. N. Chidambara Nathan, M. Pharmacy, Department of Pharmacology, K.M.C.P. Madurai and also thankful to Dr. K. Raadhika M.D., Asst. Prof., Institute of Pharmacology, Madurai Medical College, Madurai for their valuable suggestions and support to carry out this work.

\section{RESUMO}

O presente trabalho visou investigar o papel do extrato etanólico de folhas de Butea monosperma no alívio da dor neuropática pela injúria de constrição crônica (CCI) do nervo ciático induzida em ratos. Placa quente, gota de acetona, pressão na pata, testes de imersão de pelo e cauda de Von Frey foram utilizados para acessar o grau de hiperalgesia térmica, alodinia química fria, hiperalgesia mecânica e alodinia na pata trazeira esquerda e hiperalgesia térmica da cauda. Além disso, substâncias reativas com ácido tiobarbitúrico (TBARS), glutatião reduzido (GSH) e níveis de cálcio total foram estimados para acessar as alterações bioquímicas no tecido do nervo ciático. Alterações histopatológicas foram também observadas no tecido do nervo ciático. O extrato etanólico das folhas de Butea monosperma e pregabalina (servindo de controle positivo) foram administrados por 14 dias consecutivos, iniciando-se no dia da cirurgia. CCI resultou em alterações significativas nos parâmetros comportamentais e bioquímicos. Pretratamento com Butea monosperma atenuou o desenvolvimento das alterações comportamentais, bioquímicas e histopatológicas induzidas pela CCI de maneira dose dependente, comparável ao grupo pretratado com pregabalina. Esses resultados podem ser atribuídos ao potencial antioxidativo, neuroprotetor e às ações modulatórias de canais de cálcio da Butea monosperma.
Palavras-chave: antioxidante, Butea monosperma, cálcio, injúria de constrição crônica, glutatião reduzido, substância reativa ao ácido tiobarbitúrico.

\section{REFERENCES}

AdAms M, GMÜNDER F AND HAMBURger M. 2007. Plants traditionally used in age related brain disorders-A survey of ethnobotanical literature. J Ethnopharmacol 113: 363-381.

Agarwal AK, Singh M, Gupta N, SAXENA R, PURi A, Verma AK, SAXENA RP, Dubey CB AND SAXENA KC. 1994. Management of giardiasis by an immuno-modulatory herbal drug Pippali rasayana. J Ethnopharmacol 44: 143-146.

AgarWAL AK, TRIPATHI DM, SAHAi R, GUPTA N, SAXENA RP, Puri A, Singh M, MisRa RN, DubEy CB AND SAXENA KC. 1997. Management of giardiasis by a herbal drug 'Pippali Rasayana: a clinical study. J Ethnopharmacol 56: 233-236.

ALSTON RP AND PECHON P. 2005. Dysaesthesia associated with sternotomy for heart surgery. Br J Anaesth 95: 153-158.

ANONYMOUS. 2006. The ayurvedic pharmacopoeia of India, Part I. Volume II and V. Government of India, Ministry of Health and Family Welfare New Delhi, p. 128-130.

BABbar S, MARIER JF, MOUKSASSI MS, BeliVEAU M, VAnhove GF, Chanda S AND Bley K. 2009. Pharmacokinetic analysis of capsaicin after topical administration of a high-concentration capsaicin patch to patients with peripheral neuropathic pain. Ther Drug Monit 31: 502-510.

BANDYOPADHYAY U, DAS D AND BANARJEE RK. 1999. Reactive oxygen species: Oxidative damage and pathogenesis. Curr Sci 77: 658-665.

Bender G, Florian JR JA, BRAMWELl S, FIELD MJ, TAN KK, MARShall S, DEJONGH J, BIES RR AND DANHOF M. 2010. Pharmacokinetic-pharmacodynamic analysis of the static allodynia response to pregabalin and sildenafil in a rat model of neuropathic pain. J Pharmacol Exp Ther 334: 599-608.

BENNETT GJ AND XIE YK. 1988. A peripheral mononeuropathy in rat that produces disorders of pain sensation like those seen in man. Pain 33: 87-107.

CAROL W AND JANE K. 2006. Evidence-Based Treatment of Diabetic Peripheral Neuropathy. J Nurse Pract 2: 370-378.

CARRIEDo SG, SENSI SL, YIN HZ AND WeISS JH. 2000. AMPA exposures induce mitochondrial $\mathrm{Ca}(2+)$ overload and ROS generation in spinal motor neurons in vitro. $\mathrm{J}$ Neurosci 20: 240-250.

ChaPlan SR, BACH FW, POGREL JW, ChUNG JM AND YAKSH TL. 1994. Quantitative assessment of tactile allodynia in the rat paw. J Neurosci Methods 53: 55-63.

Chol Y, Yoon YW, NA HS, KIM SH And ChUng JM. 1994. Behavioral signs of ongoing pain and cold allodynia in a rat model of neuropathic pain. Pain 59: 369-376.

Daviet JC, Preux PM, Salle Jy, Lebreton F, Munoz M, Dudognon P, Pelissier J AND PERrigot M. 2002. Clinical factors in the prognosis of complex regional pain syndrome type 1 after stroke: a prospective study. Am J Phys Med Rehabil 81: 34-39. 
DWORKIN RH ET AL. 2010. Recommendations for the pharmacological management of neuropathic pain: an overview and literature update. Mayo Clin Proc 85: S3-S14.

EDDY NB, TOUCHBERry CF AND LIEBERMAN JE. 1950. Synthetic analgesics: I. Methadone isomers and derivatives. J Pharmacol Exp Ther 98: 121-137.

Ellis RJ, Toperoff W, Vaida F, VAn Den Brande G, GonZales J, Gouaux B, Bentley H AND AtKinson JH. 2009. Smoked medicinal cannabis for neuropathic pain in HIV: a randomized, crossover clinical trial. Neuropsychopharmacology 34: 672-680.

Ellman GL. 1959. Tissue sulfhydryl groups. Arch Biochem Biophys 82: 70-77.

GaO X, Kim HK, ChUnG JM AND ChUNG K. 2007. Reactive oxygen species (ROS) are involved in enhancement of NMDA-receptor phosphorylation in animal models of pain. Pain 131: 262-271.

Glass JD, Culver DG, LeVEY AI AND NASH NR. 2002. Very early activation of m-calpain in peripheral nerve during Wallerian degeneration. J Neurol Sci 196: 9-20.

GuraV SS, GulKari VD, DuRAGKAR NJ AND PATIL AT. 2008. Antimicrobial activity of Butea monosperma Lam. Gum. IJPT 7: 21-24.

Honda K, Casadesus G, Petersen RB, Perry G And Smith MA. 2004. Oxidative stress and redox-active iron in Alzheimer's disease. Ann N Y Acad Sci 1012: 179-182.

Kalita J, VAJPAYEe A AND MisRa UK. 2006. Comparison of prednisolone with piroxicam in complex regional pain syndrome following stroke: a randomized controlled trial. QJM 99: 89-95.

Kasture VS, Chopde CT AND Desmukh VK. 2000. Anticonvulsive activity of Albizzia lebbeck, Hibiscus rosasinensis, and Butea monosperma in experimental animals. J Ethnopharmacol 71: 65-75.

Kim YS, PARK HJ, Kim TK, MoOn DE AND LeE HJ. 2009. The effects of Ginkgo biloba extract EGb 761 on mechanical and cold allodynia in a rat model of neuropathic pain. Anesth Analg 108: 1958-1963.

Koltzenburg M AND SCADDING J. 2001. Neuropathic pain. Curr Opin Neurol 14: 641-647.

Kostoff RN, BRIGgs MB AND LyOns TJ. 2008. Literaturerelated discovery (LRD): Potential treatments for multiple sclerosis. Technol Forecast Soc Change 75: 239-255.

Kramer HH, He L, LU B, Birklein F AND SOMMER C. 2009. Increased pain and neurogenic inflammation in mice deficient of neutral endopeptidase. Neurobiol Dis 35: 177-183.

KRITHIKAR KR AND BASU BD. 1989. Butea monosperma. In: Blatter E, Caius JF and Mahaskar KS (Eds), In indian medicinal plants. Shiva offset press, Dehradun, p. 785-788.

Kumar N, LAFERriere A, Yu JS, LEAVITT A AND CODERRE TJ. 2010. Evidence that pregabalin reduces neuropathic pain by inhibiting the spinal release of glutamate. $\mathrm{J}$ Neurochem 113: 552-561.

LAVHALE MS AND Mishra SH. 2007. Evaluation of free radical scavengivg activity of Butea monosperma Lam. Indian J Exp Biol 45: 376-384.
LEE J AND NANDI P. 2010. Improving the management of neuropathic pain. Practitioner 254: 27-30.

LOWRY OH, Rosenbrough NJ, FARR AL AND RANDALL RJ. 1951. Protein measurement with folin phenol reagent. J Biol Chem 193: 265-275.

MANYAM BV. 1999. Dementia in ayurveda. J Altern Complement Med 5: 81-88.

MENGI SA AND DESHPANDE SG. 1995. Evaluation of ocular anti-inflammatory activity of Butea frondosa. Indian J Pharmacol 27: 116-119.

Muthuraman A, Diwan V, Jaggi AS, Singh N AND Singh D. 2008a. Ameliorative effects of Ocimum sanctum in sciatic nerve transection Induced neuropathy in rats. J Ethnopharmacol 120: 56-62.

Muthuraman A, JagGi AS, Singh N AND Singh D. 2008b. Ameliorative effects of amiloride and pralidoxime in chronic constriction injury and vincristine induced painful neuropathy in rats. Eur J Pharmacol 587: 104-111.

Muthuraman A AND Singh N. 2011. Attenuating effect of Acorus calamus extract in chronic constriction injury induced neuropathic pain in rats: an evidence of antioxidative, anti-inflammatory, neuroprotective and calcium inhibitory effects. BMC Complement Altern Med 11: 24-37.

MUthuraman A AND SOOD S. 2010. Pharmacological evaluation of tacrolimus (FK-506) on ischemia reperfusion induced vasculatic neuropathic pain in rats. J Brachial Plex Peripher Nerve Inj 5: 13-23.

NAGLER RM. 2010. CRPS: Central aspects related to locus of pain, pathophysiology, and mood. Neurology 75: 109-110.

NECKER R AND HELLON RF. 1978. Noxious thermal input from the rat tail: modulation by descending inhibitory influences. Pain 4: 231-242.

OKHAWA H, OHISHI N AND YAGI K. 1979. Assay for lipid peroxidation in animal tissue by thiobarbituric acid reaction. Analyt Biochem 95: 351-358.

OtTo M, BAK S, BACH FW, Jensen TS And SindRup SH. 2003. Pain phenomena and possible mechanisms in patients with painful polyneuropathy. Pain 101: 187-192.

PARK HJ, JoO HS, Chang HW, LEE JY, HONG SH, LEE Y AND MoON DE. 2010. Attenuation of neuropathy-induced allodynia following intraplantar injection of pregabalin. Can J Anaesth 57: 664-671.

PRAMOD K. 2006. Chronic pain syndromes (Non terminal illness). Indian J Anaesth 50: 391-396.

RANDALL LO AND SELITTO J. 1957. A method for measurement of analgesic activity of inflammed tissue. Arch Int Pharmacodyn Ther 111: 209-219.

Sai Krishna N, Ranganayakulu D, Sujatha D, Pushpa KUMARI B, VENKATESWARALU MAND GOPICHANDCHINTA. 2010. Anti-oxidant activity of the Butea monosperma leaves alone and in combination with atrovastatin. Drug Invention Today 2: 149-151.

Sehrawat A AND Sultana S. 2006. Chemoprevention by Butea monosperma of hepatic carcinogenesis and oxidative damage in male wistar rats. Asian Pac J Cancer Prev 7: 140-148. 
SEVERINGHAUS JW AND FERREBEE JW. 1950. Calcium determination by flame photometry; methods for serum, urine, and other fluids. J Biol Chem 187: 621-630.

SHAHAVI VM AND DESAI SK. 2008. Anti-inflammatory activity of Butea monosperma flowers. Fitoterapia 79: 82-85.

SHARMA N AND GARG V. 2009. Antidiabetic and antioxidant potential of ethanolic extract of Butea monosperma leaves in alloxan-induced diabetic mice. Indian $\mathrm{J}$ Biochem Biophys 46: 99-105.

SHARRNA N AND GARG V. 2009. Antihyperglycemic and antioxidative potential of hydroalcoholic extract of Butea monosperma. Lam. flowers in alloxan-induced diabetic mice. Indian J Exp Biol 47: 571-576.

ShuKla YN, Mishra M AND Sushil K. 2002. Euphane triterpenoid ester and a pterocarpan fron Butea monosperma leaves. Indian J Chem 41B: 881-883.

SOMAN I, MENGi SA AND KASTURE SB. 2004. Effect of leaves of Butea frondosa on Stress, anxiety, and cognition in rats. Pharmacol Biochem Behav 79: 11-16.

SOMMER C AND SCHAFERS M. 1998. Painful mononeuropathy in C57BL/Wld mice with delayed wallerian degeneration: differential effects of cytokine production and nerve regeneration on thermal and mechanical hypersensitivity. Brain Res 784: 154-162.
Stanciu M ET AL. 2000. Persistent activation of ERK contributes to glutamate-induced oxidative toxicity in a neuronal cell line and primary cortical neuron cultures. J Biol Chem 275: 12200-12206.

Sudoh Y, Desai SP, Haderer AE, Sudoh S, Gerner P, Anthony DC, De GiRolami U AND Wang GK. 2004. Neurologic and histopathologic evaluation after high volume intrathecal amitriptyline. Reg Anesth Pain Med 29: 434-440.

SUZGEC-SELCUK S AND BIRTEKSOZ AS. 2011. Flavonoids of Helichrysum chasmolycicum and its antioxidant and antimicrobial activities. S Afr J Bot 77: 170-174.

VARIER SPV. 1995. Indian Medicinal Plants. Long man publisher, Madras.

WoOlF CJ AND MANNION RJ. 1999. Neuropathic pain: Aetiology, symptoms, mechanisms and management. Lancet 353: 1959-1964.

XIE X AND BARRETT JN. 1991. Membrane resealing in cultured rat septal neurons after neurite transection: evidence for enhancement by $\mathrm{Ca}^{2+}$ triggered protease activity and cytoskeletal disassembly. J Neurosci 11: 3257-3267. 